\title{
El imaginario textil griego y la comunicación
}

The Greek textile imaginary and communication

Daniel H. Cabrera Altieri, Universidad de Zaragoza - danhcab@unizar.es

Resumen

El articulo expone una interpretación del imaginario textil griego tal como aparece delineado en la bibliografía especializada y en los autores clásicos y en relación con explicación del fenómeno de la comunicación. La comunicología ha reconocido siempre en la Grecia clásica la retórica del ágora, pública y masculina, como un modelo de comunicación. Sin embargo el silencio es total respecto de actividad textil que representaba el tipo de comunicación matricial propia del oikos, doméstico y femenino. Se propone recuperar este olvido para repensar la comunicación.

Palabras clave

Imaginario social, comunicación, lo doméstico, lo femenino, lo textil, Grecia clásica.

Sumario

1.- Introducción. 2.- Metodología. 3.- La comunicación y el poder. 4.- La voz del telar, la palabra de la plaza. 5.- El tejido, voz y astucia de las mujeres. 6.- Conclusiones. 7.- Bibliografía 


\section{Intoducción}

El presente trabajo constituye una parte de un proyecto mayor que se propone recuperar y formular el imaginario textil de la comunicación y su olvido en las teorías e historias de la información y la comunicación.

La teoría de los imaginarios sociales constituye la perspectiva desde la cual se realiza esta interpretación del fenómeno de la comunicación Un enfoque que articula la filosofía de Cornelius Castoriadis (1993) y la antropología de Gilbert Durand (2004) (Cabrera 2006a) en sus dimensiones hermenéutica y ontológicas en relación con el aspecto tecnológico de la comunicación (Cabrera 2004 y 2006b). Es decir que se distancia del uso más extendido de dichas teorías/concepto que se aplican al análisis de la representación de algo 0 alguien (la mujer, los inmigrantes, etc.) en un determinado medio (las revistas de moda, la prensa española, etc.) a través de un análisis de contenidos y/o del discurso del mismo. Como se ha expuesto en otro lugar (Cabrera 2011) este uso instrumental de la teoría la vacía de contenido y la desarma en su capacidad de análisis crítico de la cultura y la sociedad.

Interpretar un fenómeno como "imaginario" implica considerarlo como un conjunto de imágenes y representaciones (lingüísticas, sonoras, visuales, etc.) unidas indisociablemente a un conjunto de afectos y deseos característicos. Imagen e imaginación constituyen la clave de lo imaginario tanto en su dimensión ontológica como hermenéutica.

En este sentido se entiende por "imaginario textil" el conjunto de imágenes, afectos y deseos que el fenómeno de la actividad del entrelazado de hilos (del material que sean) por el que se crea un tejido (telas, ropas, etc.). Lo textil comprende, en un primer sentido, la actividad manual -tejer- , el producto -el tejido-, la ejecutora -tejedora/s- según modalidades históricas concretas. En un segundo sentido, lo textil se interpreta como ícono y metáfora que explica la comunicación.

El "imaginario textil griego" se refiere a la interpretación del fenómeno textil de la Grecia clásica en el contexto de otras actividades y costumbres que la contextualizan y la definen. Abundan las referencias a la comunicación del ágora, pública y masculina pero se ha omitido la comunicación en torno a la actividad del tejer y el tejido. Lo textil representa un tipo de acción del oikos, de lo doméstico y lo femenino, que constituía la base de la formación del futuro ciudadano. El principal resultado de semejante análisis es la consideración de lo textil como una importante imagen, símbolo y metáfora de la comunicación cuya presencia ha sido olvidada en las historias y las teorías de la comunicación.

El presente artículo se propone interpretar la actividad y la mitología textil de la Grecia clásica para llamar la atención de su importancia en la investigación en comunicación.

\section{Metodología}

La investigación sobre el imaginario textil griego se basó en la interpretación de los autores de referencia en el estudio de la mitología y las costumbres de la Grecia clásica junto a una revisión de los principales textos de los autores clásicos. Todo ello organizado en dos ejes. En el primero se analizaron las costumbres griegas de la época clásica con referencia a las actividades textiles y su papel en esa sociedad (epígrafe 4) y en segundo lugar, la mitología representativa referida a la simbología de lo textil (epígrafe 5). Esta lectura se contextualizó en una revisión de la historia y de las teorías de la comunicación buscando referencias explícitas al mundo textil.

En todo el proceso el enfoque fue el de una hermenéutica de los imaginarios sociales tal como se ha sistematizado en otro lugar (Cabrera 2006). Este punto de vista propicia la búsqueda de significaciones, imágenes, símbolos y mitos que organizan las constelaciones del fenómeno de la comunicación. Una organización imaginaria -por lo tanto real y actuante- que conduce a manifestar nuevos nexos entre lo textil y lo comunicativo. Se dice constelación porque las relaciones que se buscan entre los fenómenos no son necesariamente de tipo lógico causal sino también relaciones de asociación, de semejanza, de contigüidad o de oposición. Este conjunto de conjunciones permiten organizar alquímicamente fenómenos aparentemente contradictorios o sin relación que sin embargo se manifiestan según una afinidad electiva.

\section{La comunicación y el poder}

Harold Innis $(2007 ; 2012)$ fue de los primeros en señalar que cada medio de comunicación tiende a crear un monopolio de conocimiento. El monopolio intelectual de los monjes medievales, basado en el pergamino, fue socavado por el papel y la imprenta, así como el "poder monopolista sobre la escritura" que ejercían los sacerdotes egipcios en la era de los jeroglíficos se vio subvertido por los griegos y su alfabeto.

La historia de los medios de comunicación muestra cómo las teorías que buscan explicar la comunicación se han centrado en los medios técnicos- de comunicación y en particular de aquellos medios que eran usados para sostener el poder político de una sociedad. Todavía más, el modo de explicar esos medios toma la perspectiva de una teoría que busca comprenderlo desde la óptica del poder, para sostenerlo o para criticarlo, pero sin cuestionar su centralidad en tanto artefacto técnico. Aún está por escribirse la historia de los medios de comunicación de los espacios subalternos. Entre ellos se encuentra el espacio doméstico de la Grecia clásica. Un espacio femenino donde todo ciudadano libre aprendía las bases culturales y míticas que luego los poetas y la ciudad desarrollarían.

La óptica del poder, común a defensores y detractores, es posible rastrearlo, por ejemplo, en las explicaciones actuales de las tecnologías digitales de la comunicación con internet en el centro de todas ellas. Las genealogías de dichas tecnologías ahonda el concepto de red (web e internet) indagando la matriz imaginaria moderna que relaciona las redes de caminos y canales, de trenes e hilos telegráficos, redes eléctricas, etc. hasta llegar a la red de redes -internet- como clave para la comprensión del presente y el futuro de la llamada sociedad de la información (Mattelart 1995 y 2000; Castells 1996 y 2001; Gleick 2012). 
Sin embargo, dichas historias y genealogías de la comunicación interactiva digital no han despertado aún ninguna curiosidad sobre el imaginario que los hilos, los nudos, las telarañas, etc. esconden e inundan nuestra imaginación lingüística desde el neolítico -cuando se inventa el huso y el telar-. En el vocabulario cotidiano actual de las lenguas europeas y en particular en la española permanecen escondidos una serie de palabras y expresiones que reflejan la pervivencia de lo textil como metáfora de la comunicación y del sentido. Expresiones como el hilo del discurso, el nudo de la cuestión, seguir el hilo, tirar del hilo, el nudo gordiano, etc. o palabras como texto 0 técnica cuya etimología se refiere a lo textil. Lo textil asoma como una imagen arquetipal presente en nuestra imaginación cultural pero no considerada explícitamente en la comunicología.

Interpretar lo textil implica distanciarse metodológicamente de la comunicación en su relación con los espacios de poder público (el ágora) y adentrase en los espacios subalternos de lo femenino y lo doméstico (el oikos) para esbozar una comprensión diferente del fenómeno comunicativo.

\section{La voz del telar, la palabra de la plaza}

"A los hombres la guerra, a las mujeres los trabajos de la lana" (Homero, llíada VI, 492)

Las teorías de la comunicación tienen muy claro el legado de la antigua Grecia y señalan a la Retórica aristotélica en el origen de la comunicación política. El ágora es el modelo de comunicación -pública, democrática y masculina- legado por la Grecia clásica. Por el contrario hay una total ausencia de referencias al espacio del oikos como espacio de comunicación organizado por la mujer y donde convivían todos -mujeres y varones, adultos y menores, libres y esclavos-.

"Si el espacio exterior de la polis es pensado como el lugar del intercambio de ideas, el espacio del gineceo, regido por el ritmo del telar, es considerado como generador de un tipo de palabra diferente del logos, lenguaje nacido en la oscuridad de los interiores que siempre tiende a interceptar la comunicación y que a veces la convierte en auténtico desafío intelectual" (Iriarte 1990:130).

Alrededor de esta actividad doméstica se desarrollaban diálogos, cantos y enseñanzas que eran el corazón de la casa, de la formación de los ciudadanos y de la transmisión cultural del mundo heleno, en especial el femenino. Antes de que la ciudad separara a los niños varones del espacio doméstico, todos habían aprendido en torno a lo textil la "lengua materna" y las creencias de su sociedad. Sin embargo, ni las historias ni las teorías de la comunicación hacen referencia a la actividad textil griega como espacio matricial -matriz y nutriente- de lo que llamamos comunicación.

\section{1.- El tejer}

El trabajo de la lana "en todas sus etapas, constituye la actividad principal de las mujeres en el mundo griego, y sirve para definir su papel doméstico y social, paralelamente a su función reproductora" (Frontisi-Ducroux 2006:237). El acto de tejer sirve de metáfora a la unión sexual, el entrelazamiento (sýmplegma) especialmente cuando el acto sexual tiene una finalidad engendradora.

"Tejer se describe como cruzar dos hilos de diferente género: el hilo de la urdimbre, cuyo nombre, stemon, es masculino, y es grueso y sólido; y la kroke, palabra femenina, la trama, más fina y más flexible" (p. 238).

La actividad de tejer en la antigua Grecia era desarrollaba por mujeres y fundamentalmente en la casa.

"La lana era llevada a la casa; allí se la batía y se la cardaba (trabajo de las cardadoras), para transformarlas, a fin de que las hilanderas, con la ayuda de la rueca y del huso, sacasen lo hilos; este trabajo era desempeñado principalmente por las jóvenes de la casa. Se tejían los hilos en los telares para hacer telas, lo que era una ocupación honrosa de la dueña de casa, las mujeres particularmente hábiles en este arte sabían adornar los tejidos con dibujos variados" (Zielinski 1987:43).

La actividad doméstica del tejido constituye el espacio de la voz femenina:

"Junto al telar se reúne la mitad femenina de la casa: el ama de casa, las hijas, las sirvientas y los niños; es el lugar donde, mientras trabajan, cantan hermosas canciones, como lo hacen en la Odisea las diosas seductoras Circe y Calipso; donde las nodrizas y las abuelas cuentan a los niños los cuentos que condena Platón; donde los niños, incluidos los chicos hasta los siete años, se familiarizan con los relatos míticos" (Frontisi-Ducroux 2006:240).

El telar -"uno de los inventos más revolucionarios del Neolítico" (Eiroa 1994:51) - en el contexto griego

"...es el instrumento a través del cual se transmite el patrimonio cultural a los futuros ciudadanos, a los que marcará para siempre. Y esta transformación se realiza por medio de la voz de las mujeres, mucho antes de que los poetas tomen el relevo en esta función educativa. Una formación audiovisual en la que las palabras y las imágenes tejidas se entremezclan y conjugan" (Frontisi-Ducroux 2006:240).

La actividad de tejer, el lugar que ocupaba en el espacio femenino de lo doméstico, constituye la matriz imaginaria de lo que se llamará comunicación, así a secas, sin adjetivos. El entrelazado de los hilos, el entrelazado de la gente de la casa, el entrelazado de los mitos. La 
mujer que organiza, que teje, que engendra, que narra, que canta y junto a la cual se reúne la casa.

El arte de tejer griego se representa en la literatura como el "terreno metafórico privilegiado en el que se construye la presencia y la esencia de un femenino imaginario" (Papadopoulou-Belmehdi 1996: 25). Es ese terreno femenino donde se produce un tipo de comunicación a partir de un entrelazado realizado con las manos y acompañado con la oralidad. La habilidad manual da a luz las imágenes de las historias y mitos contadas. El arte del tejido como actividad, como voz y como imagen no han figurado en la historia de la comunicación, sin embargo, han permanecido escondidos hasta la actualidad en expresiones y vocabularios cotidianos referidos al sentido y a la comunicación (el hilo del discurso, el nudo de la cuestión, seguir el hilo, tirar del hilo, etc.) También en las etimologías de las palabras como texto o técnica. La palabra "texto", por ejemplo, que a través del latín nos llega como tejer, trenzar, entrelazar y que a pesar de que suele interpretarse como el producto acabado interesa destacarlo, como sostuvo Barthes, que desde "la idea generativa de que el texto se hace, se trabaja a través de un entrelazado perpetuo" (Barthes 1974:81). Esa actividad y ese movimiento es el que está latente y que simboliza y significa la cuestión central de la comunicación.

Interesa el oficio de tejer no sólo como una habilidad artesanal como cualquier otra, sino en su significación cultural para comprender la comunicación desde lo doméstico y lo femenino en oposición a la comunicación política masculina. Ambas efímeras en tanto son orales, ambas constructoras. Mientras la comunicación política dio origen a la retórica y a la política, la comunicación doméstica fue clave en transmisión cultural. Sin embargo, mientras la comunicación política permaneció como un imaginario explícito; la comunicación domésticacomo sucede a las telas con el paso del tiempo- pasó desapercibida y luego olvidada.

\section{2.- El tejido y la política}

La actividad del tejido analizada en el contexto de lo doméstico tiene, al menos, dos referencias clásicas donde se la utiliza como modelo para entender lo público, la política. Aristófanes en su comedia Lisistrata (411 a.C.) y Platón en El político (367-361 a.C.) recurren a la actividad del tejer y las tejedoras manifestando un gran conocimiento de la técnica del tejido. El modo en que ambos presentan el tejido en relación con la política anima la idea de que la metáfora textil puede ser un recurso para pensar la comunicación.

Aristófanes escribió un conocido pasaje sobre el femenino arte de tejer que según hace decir a su protagonista "si tuvieras una pizca de sentido común, según nuestras lanas gobernaríais todo".

"COMISARIO. ¿Y cómo os las vais a arreglar vosotras para reconciliar y poner fin a tal cantidad de asuntos enmarañados en las ciudades griegas?

LISISTTRATA. Muy simple.

COMISARIO. ¿Cómo? Explícamelo.

LISÍSTRATA. Igual que el hilo, cuando se nos ha enredado, lo cogemos así (Muestra con gestos lo que está diciendo), y con los husos por un lado y por otro, lo traemos a su sitio, así también desenmarañaremos esta guerra, si es que nos dejan hacer, poniendo las cosas en su sitio por medio de embajadas a un lado y a otro.

COMISARIO. ¿Así que con lanas, hilos y husos, os creéis que vais a poner fin a unos asuntos tan terribles? ¡Qué necias!

LISISTRRATA. Sí, y también vosotros, si tuvieras una pizca de sentido común, según nuestras lanas gobernaríais todo. COMISARIO. ¿Cómo? A ver.

LISÍSTRATA. Primero, a la ciudad como al vellón de lana, después de haberle quitándola mugre lavándola en un baño, habría que ponerla sobre un lecho, apalearla para que eche a los sinvergüenzas y sacarle los abrojos; y a esos que se reúnen y se aglomeran junto a los cargos públicos, separarlos con el cardado y arrancarles... las cabezas. Después habría que esponjar la buena voluntad común y echarla en un cestito, mezclando a todos, a los metecos, a los extranjeros que sean amigos nuestros, ya los que tengan deudas con el Estado: también a esos mezclarlos ahí. ¡Por Zeus!, y las ciudades, todas las que son colonias de esta tierra, habría que tener una idea clara de que para nosotros son como los copos de lana que están cada uno por su lado; luego se cogen estos copos que forman cada una de ellas, se reúnen y se juntan en uno solo, y después se hace una gran bola y, con ella, se teje un vestido para la gente."

Aristófanes pone en boca de Lisístrata una opinión sobre asuntos políticos. La comedia, a diferencia -como veremos- de lo que sucede en Platón, "habla desde la mujer" lo cual es

"algo imaginativo e inexistente, dado que la mujer ateniense no participaba en absoluto en los asuntos políticos, era una breve mirada al mundo de las imágenes, al mundo de lo privado (...) enfrenta a los ideólogos de la política con la contradicción de su falta de perspectiva privada y familiar, de manera que todos sus planes no pasan de lo utópico y su capacidad sólo es supuesta" (González Escudero 2007:76).

El tejido, desde la mirada femenina, permitiría ver una solución a las malas políticas que conducen a la guerra. Mezclando a todos los individuos y a todas las ciudades "luego se cogen estos copos que forman cada una de ellas, se reúnen y se juntan en uno solo, y después se hace una gran bola y, con ella, se teje un vestido para la gente". Mezclar, reunir, juntar, tejer... crear lo nuevo, lo que protege.

En un sentido similar Platón, desde una óptica pública y masculina, pone en boca del Extranjero (\$279c-280a) una disquisición sobre los géneros de la defensa, la protección, la cobertura, la envoltura y el entrelazamiento. Filosóficamente este enfoque tiene una gran relación con las etimologías de textil, texto, técnica, tectónico, techo, tejado. Campo semántico para pensar la relación de lo textil como protección y envoltura con lo tectónico cueva protectora, lo textual como cobertura de sentido y la comunicación como lo matricial. Lo textil como entrelazamiento creador de envolturas y la técnica como destreza del trenzado creador. En estos sentidos, la comunicación sería el entrelazado creador, la interacción creadora de individuos y de sociedad.

"EXTR. Pues bien: todo cuanto fabricamos y adquirimos nos es útil, ya sea con vistas a hacer algo, ya como defensa contra el sufrimiento; entre estas defensas, unas son remedios divinos o humanos, otras, 
protecciones; de las protecciones, unas son armamentos para la guerra, otras coberturas; las coberturas son, o bien como cortinajes extensibles, o bien reparos contar las escarchas o los ardores del sol; estos reparos se clasifican en albergues y ropas; entre las ropas unas se extienden por bajo, otras sirven para envolver; las que envuelven son, unas de una sola pieza, otras, de varias; entre las de varias piezas, las hay perforadas, o bien sin perforar y entrelazadas; las no perforadas se hacen con fibras de plantas terrestres o con crines; las de crines están pegadas con agua y tierra, o bien entrelazadas en sí mismas. Y bien: a estas defensas y ropas que se confeccionan entretejiendo sus mismos hilos les damos el nombre de vestidos; e igual que entonces llamamos "política" al arte de cuidar la "polis"..."

Platón define con toda claridad el arte de tejer como entrelazamiento (§281a) (Couloubaritsis 1995:107-162):

"EXTR. Lo que se hace con el tejido es algo así como un entrelazamiento, ¿no?

EL J: SÓCR. Sí.

$(\ldots)$

EXTR. (...) a la fabricación de la urdimbre y la trama se les llama arte de tejer"

El arte de tejer en tanto se distingue de las artes auxiliares por las que se fabrican los instrumentos necesarios ( $\$ 281 \mathrm{~d}$, e) produce, es la causa en sí, la causa primaria de lo fabricado, del producto. Estilísticamente el diálogo parece como un tejido realizado por el tejedor Platón (Castoriadis 2003:57) mediante el método dialéctico procediendo a la división de géneros en especies. A través de ello expresa la profunda relación entre la institución de la polis (la sociedad) y la institución del individuo (Castoriadis 2003).

Platón ve en el arte de tejer un paradigma de la política (\$279 a, b) (González Escudero 2007) y este enfoque epistemológico lo asumimos para comprender la comunicación. El paradigma es el arte de tejer en sí (entrelazamiento, urdimbre y trama), su actividad (arte manual acompañado de historias) y su producto (soporte de imágenes).

\section{El tejido, voz y astucia de las mujeres}

Los simbolismos del tejido, del telar y de las tejedoras han sido transmitidos a través de diferentes narraciones y mitos (Buxton 2000: 123ss) cuyo imaginario ha permanecido en el vocabulario occidental. Las historias y los mitos abundan. Aracné, Penélope o las Moiras representan diferentes aspectos de la vida humana y el destino entendidos desde la urdimbre, la trama, el hilo, la rueca, las tijeras, la acción de tejer y destejer. Se destacan brevemente a continuación detendremos dos: Procne y Aracne.

\section{1.- Procne: Filomena, la voz del telar}

Conocida fundamentalmente por la versión de Ovidio (Las metamorfosis, VI), cuenta la historia de Procne, la hija del rey de Atenas Pandión I, que se casó con Tereo como resultado de una alianza contra los enemigos bárbaros de la polis ática. Procne echaba de menos a su hermana Filomena. Tereo la lleva de viaje a Tracia, con el fin de que acompañe a Procne, que ha sido madre hace algunos años. Pero Tereo traiciona su rol de custodio, violándola antes de llegar al palacio, cortándole la lengua para que no pueda denunciarlo y dejándola presa en una casa del bosque. Filomena logra comunicarse con su hermana enviándole un tejido, tras lo cual las hermanas buscan la venganza y consuman el infanticidio de Itis, el hijo de Tereo y Procne. Tereo termina devorando sin saberlo a su propio heredero, cocinado por Procne -su madre-, para luego perseguir enloquecido a las hermanas, al enterarse de lo ocurrido. En medio de esta persecución, los tres protagonistas son transformados por los dioses en pájaros.

Este relato tradicional presenta a Tereo como un arquetipo clásico del bárbaro y del abuso sexual. Mientras, las mujeres del relato consuman su venganza recurriendo a saberes femeninos domésticos, tradicionales en el mundo antiguo, el tejido y la cocina, en los que empeñan principalmente astucia y habilidad.

El trabajo con la lana ocupa un lugar central en la historia ya que es el tejido el medio de comunicación, el medio por el que Filomena consigue comunicarse con su hermana. A falta de lengua, telar para comunicar. A falta de voz, tejido como narración.

La amputación de la lengua de una mujer adquiere una connotación especial, es la supresión de la voz que se supone diferente a la del hombre "una voz que oscila entre el silencio impuesto por la sociedad y la desenfrenada locuacidad que se supone propia de las mujeres" (Frontisi-Ducroux 2006: 237) y que sostiene una complicidad de género que deja fuera al hombre. Filomena convierte "la voz de la lanzadera" (Aristóteles, Poética, 16) en su voz, en su comunicación de mujer a mujer con su hermana.

"Si Filomena recurre a su telar para sustituir su lengua cortada, es, en primer lugar, porque es eso lo que sabe hacer (...) Filomena consigue que llegue a manos de Procne, que la cree muerta, el tejido delator en el que describía su desdicha" (Frontisi-Ducroux 238) Filomena al tejer su tela relata silenciosamente lo que sustituye al lenguaje sonoro del que ha sido privado. La oposición entre la voz y lo escrito es importante en el imaginario griego, como lo es, dentro del lenguaje silencioso, la de la escritura y la imagen (Frontisi-Ducroux 238)

Entre voz y escrito se introduce el alfabeto y la influencia de éste en la oralidad (Ong 2006) pero en el lenguaje silencioso la escritura y el dibujo mantiene una tradición paralela hasta llegar al siglo XX, el siglo de la imagen (McLuhan 1996). Sin embargo, la oralidad de ágora y la oralidad del oikos parecen correr distintas suerte, como diferentes es la imagen transmitidas por diversos medios (jarrones, frisos, etc.).

Para el relato que hace Filomena de sus desdichas subraya la distancia entre la palabra articulada y su sustituto. Permite además insertar entre ambos los lenguajes intermediarios como el habla bárbara de los tracios (entre quienes las dos hermanas se encuentran exiliadas), el gorgojeo ininteligible de la golondrina (en lo que se convertirá Filomena), el canto poético del ruiseñor (en lo que se transformará Procne), e incluso la escritura, a pesar de ser imposible en una mujer iletrada."La muda sólo puede "hacerle un dibujo" a su hermana" (Frontisi- 
Las figuras tejidas constituyen el lenguaje específicamente femenino. Helena de Troya reproduce en su telar las hazañas de los héroes y los sufrimientos de los que ella es causa. El que teje y desteje Penélope que le sirve para retrasar la acción, un lenguaje eficaz en su negación misma. Si Filomena teje silenciosamente su historia para su hermana, es porque a su lado ha aprendido a practicar estos dos lenguajes de mujeres, paralelos, alternativos y equivalentes. "El lenguaje silencioso al que recurre la tejedora es en sí mismos el indicio de los secretos que guarda la comunidad charlatana de las mujeres y a los que los hombres no tienen acceso" (Frontisi-Ducroux 240). Se les atribuía a las mujeres un saber misterioso, incluso inquietante, obsesión masculina que se expresa bajo diversas formas. La astucia (mētis) (Detienne; Vernant 1988) propia de las mujeres se opone a la fuerza y el pensamiento lógico de los hombres y "es potencialmente peligrosa y hostil para el orden masculino dominante" (González González 2008: 24). Astucia e inteligencia que "que fue íntimamente asociada con las nociones de realización y utilización del tejido" (Iriarte 1990:32).

\section{2.- Aracne, una historia de telares y tejidos}

Aracne era conocida por su gran habilidad para el tejido (Ovidio, Metamorfósis, VI). Las alabanzas la convirtieron en una persona engreída y sostenía que sus habilidades eran superiores a las de Atenea, la diosa de la sabiduría, la guerra y la artesanía. La diosa se enfadó y adoptando la forma de una anciana reprendió a Aracne por su ofensa a los dioses. La mortal propuso un concurso de tejido en el que pudiera demostrar su superioridad. Atenea se quitó el disfraz y el concurso comenzó. Palas tejí la escena de su victoria sobre Poseidón. Según Ovidio, el tapiz de Aracne representaba algunos episodios de infidelidades de los dioses disfrazados de animales: Atenea admitió que la obra de Aracne era perfecta, pero se enfadó mucho por la irrespetuosa elección del motivo. La diosa destruyó el tapiz y el telar de Aracne golpeándolos con su lanzadera, y también golpeó en la cabeza a la joven. Aracne, que advirtió su insensatez y quedó embargada por la vergüenza, huyó y se ahorcó. Atenea se apiadó de Aracne y convirtió la soga en una telaraña y a la propia Aracne en araña.

La historia de Aracne se desarrolla como una historia muy femenina. El tejido es la aportación de las mujeres a la civilización. Frente a los pueblos salvajes que se visten con pieles de animales, el tejido provee vestimenta y abrigo como signo de civilización. "Tejiendo es como la mujer puede afirmarse y es en ese terreno donde corre el riesgo del exceso" (Frontisi-Ducroux 2006:254). El exceso del encierro "en el vaivén hipnótico de la lanzadera. Una alienación que da seguridad... que hace que se olvide el mundo exterior (...) o el exceso del orgullo desmedido, la exaltación de la técnica que domina... este es el error de Aracne" (Frontisi-Ducroux 254).

La madre de Aracne había muerto, no fue educada por una mujer. Su educación estaba incompleta. "Le faltaba algunas de las cosas que una joven debe saber, todo lo que transmite una madre: la reserva, la modestia, la discreción, el silencio y, en particular, que los asuntos de sexo son secretos que deben seguir siendo secretos" (Frontisi-Ducroux 254). Educada por un hombre, su padre, rechaza la tutela de una mujer, no respeta la edad y al proclamarse autodidacta reconoce la falta de transmisión materna.

Aracne demuestra en el concurso superioridad absoluta. Su hermosa labor, sin embargo, su tapiz respira deseo y placer. Retrata a los dioses masculinos en el libre juego del erotismo y la seducción. Atenea que rechaza para sí misma la sexualidad reacciona ante el sexuado tapiz de Aracne.

"Es probable que la doncella hubiera tenido que ajustarse a un tema más casto, limitarse al tejido virginal, en lugar de lanzarse precipitadamente al tejido para matrimonial de las divinidades... También en este punto, la ausencia de una madre ha sido fatal para ella" (Frontisi-Ducroux 269).

Humillada Aracne se cuelga, como la araña que será colgada constantemente de su hilo. El tejido de la araña se hace con un solo hilo. El tejido de la mujer se hace entrelazando dos hilos, la urdimbre y la trama -lo masculino y lo femenino- y como la relación sexual de hombre y mujer crea algo nuevo.

"El acto creador de la araña es ciertamente singular. Su fertilidad no está relacionada con la cópula con el macho (habitualmente más pequeño, menos perceptibles en sus costumbres y construcciones y de vida mucho más breve), ni con la puesta. La creación araneológica es un acto aparentemente asexuado, pues su obra es la tela, el cosmos." (Melic 2002:112)

Por otra parte el hilo de la araña es de un solo color que se comparaba con la niebla o la bruma, no tiene color y por supuesto imágenes. Aracne, la tejedora, pintora de los amores de los dioses, fue privada para siempre "de sexo, de color y de imágenes" (Frontisi-Ducroux 2006:275). Sin embargo, Aracne/araña representa esa capacidad de creación -de técnica y sabiduría- y de caza. Actividad que era considerada como un sector privilegiado de la astucia (mētis) del cazador y de pescador. Aracne será la admiración de los sabios pero privada para siempre de la urdimbre masculina y, por lo tanto, de la unión sexual reproductora (el entrelazamiento, sýmplegma).

Esta araña que con su actividad se convierte en una metáfora del hilado y de lo femenino, del placer y de la astucia y por todo ello, en la productora del hilo conductor -el medio de comunicación- entre la humanidad y el cosmos.

"La construcción de telas, la forma en que algunas especies se deslizan por los hilos, y la estructura geométrica de esas construcciones relacionan a la araña con el hilado y con el destino, o la convierten en medio de comunicación -hilo conductor- entre el hombre y el universo o los dioses. La araña debe ser necesariamente mujer. Por un lado, es Madre y sólo las mujeres son capaces de parir. Por otro, la araña es hilandera, actividad tradicional exclusiva de las mujeres. En muchos sentidos, la araña es la esencia de lo femenino, incluido el lado oscuro del sexo, por lo que tiene de irresistible y de debilidad para el varón teóricamente dominante; placer y peligro a un tiempo. Peligro, porque la araña es una experta cazadora, un ser capaz de diseñar trampas invisibles y engaños invencibles. Es la personificación de la 
astucia, de la sabiduría ancestral aplicada a la obtención del placer (sea una presa a la que devorar o un encuentro sexual... que puede acabar del mismo modo)" (Melic 2002 116)

La habilidad de la mujer, tejedora y reproductora, tiene también, como la araña, un contexto de cueva, de oquedad. La mujer griega debía permanecer en su casa, allí ella gobernaba las labores interiores de mantenimiento. La casa/cueva de la mujer/araña no era la cueva iluminada y contemplativa de Platón sino la cueva de la oscuridad del repetitivo mundo de la labor, en el sentido de Arendt.

\section{Conclusiones}

La interpretación de los símbolos, las metáforas y las imágenes de la actividad textil, el contexto y los instrumentos del tejer y el tejido invita a recuperar el papel de lo doméstico y lo femenino en la explicación del fenómeno comunicativo. Aún así es necesario profundizar la investigación para dar una definición acabada de una comunicación matricial como diferente de la comunicación patriarcal.

Se ganaría mucho si se recuperara del olvido (¿y/o negación?) el tejer y el tejido como su imaginario propio porque recuperaría, entre otros espacios simbólicos, el hogar, lo femenino, lo subalterno, la imagen y el gesto. No solo lo femenino (en Grecia algunas mujeres podían hablar en público) sino lo femenino como espacio de sujeción y de dominación (no eran ciudadanas pero daban a luz y educaban ciudadanos). Del análisis derivan algunas ideas para pensar la comunicación que solo enumeramos.

A.- La investigación actual sobre los medios interactivos digitales obliga a revisar el imaginario tecnológico media-céntrico. En el imaginario tecnocomunicacional la idea de código como materia prima de lo digital participa del imaginario de trama y urdimbre; el codificador como tejedor/a y la imagen que simboliza lo digital -la imagen pixelada o la interfaz de las órdenes de los sistemas operativos- aparece como una reminiscencia del tejido. Estas relaciones de semejanza, contigüidad u oposición, metáfora o metonimia, etc. fundamentan el lenguaje como el mito referido a la comunicación. Pero también la realidad funcional de los aparatos cuyo principal ejemplo es la tarjeta perforada.

La tarjeta perforada contenía la información en forma de perforaciones según el código binario de superficie-agujero y fue el primer medio utilizado para ingresar información e instrucciones a los ordenadores. Esas tarjetas fueron un invento textil. Un invento usado por Joseph Marie Jacquard (1752-1834) en sus telares que un siglo después pasó a los primeros ordenadores. Con esa misma lógica se utilizaron las cintas perforadas que actualmente han sido reemplazadas por medios magnéticos y ópticos de ingreso de información. Sin embargo, muchos de los dispositivos de almacenamiento actuales, como por ejemplo el CD-ROM también se basa en un método similar al usado por las tarjetas perforadas.

La tarjeta perforada y su posterior deriva constituyen sólo un ejemplo del imaginario que actúa en nuestra cultura, en nuestra imaginación y en nuestros aparatos. Un estudio del código binario en clave de imaginario probablemente nos acercaría al paradigma textil de la comunicación informática del entrelazamiento, de la urdimbre y la trama.

B.- Las historias de la comunicación establecen una "evolución" de la oralidad a la escritura alfabética, luego continuaría la imprenta y finalmente los medios eléctricos con la primacía de la imagen y la digitalización. Desde el punto de vista comunicacional, lo textil nos obliga a destacar las "oralidades", en plural, para dar cuenta de dos oralidades, la pública y la doméstica, la masculina (comunicación patriarcal) y la femenina (comunicación matricial), la del poder -político o económico- y la subalterna o reprimida. Una de esas oralidades es la que evoluciona hacia la escritura y culmina con la imprenta. Una escritura que con el tiempo llegará a "traducir" toda la oralidad desde una escritura moldeada desde un tipo especial de oralidad, la del poder. Cabría preguntarse cómo sería una escritura evolucionada desde la oralidad oculta y subalterna.

"Cuando se habla de escritura, ésta va asociada a una mirada evolucionista en la que la cúspide sería la escritura alfabética, "la escritura completa", la que representa la palabra hablada, con sus antecedentes en la logo-silábica y la silábica. Los peldaños precedentes serían lo que llama la "no escritura"..." (Ramiro Beltrán et alia. 2008:225)

Esta idea, por supuesto, se inscribe dentro del campo abierto por Derrida (1998) con su crítica al logocentrismo y a la metafísica de la escritura fonética. Lo que permite imaginar un conjunto de inscripciones diferentes que, a falta de un reconocimiento, podríamos postular como una forma de ser semejante al arte del tejido: gestualidad, reunión, espacios propios, imágenes, metáforas. Esa "escritura" sería una manera de comunicación subalterna y creadora.

Históricamente solo se conoce una única sociedad sin alfabeto ni imprenta que se organizó en torno a la comunicación textil, los Incas. Un imperio de una gran extensión territorial, con una complejidad cultural muy importante y que con razón fue llamado el "imperio textil" (Corcuera 2010:89). Allí el tejido era un organismo vivo, posiblemente, a la manera como lo era en la antigua Grecia en el marco de los espacios domésticos.

C.- El imaginario textil, como ya ha sido comentado, implica el arte de tejer en sí (entrelazamiento, urdimbre y trama), su actividad (arte manual acompañado de historias) y su producto (soporte vivo de imágenes). El imaginario textil griego permite postular una nueva comprensión comunicación humana. Tal vez, como se ha afirmado, "los medios de comunicación constituyen las ruecas del mundo moderno y, al utilizar estos media, los seres humanos se convierten en fabricantes de tramas de significado para consumo propio" (Thompson 1998:26). Se trataría de ensayar esta interpretación tomándose en serio lo que las metáforas y los símbolos del imaginario textil nos dicen desde tiempo ancestrales.

En síntesis, una genealogía del imaginario textil de la comunicación permitiría reconsiderar las teorías de la comunicación desde una perspectiva distinta y olvidada desde el inicio mismo del pensamiento europeo occidental. Lo expuesto aquí es solo un primer paso en ese camino. 


\section{Bibliografía}

Barthes, R. (1974) El placer del texto, Buenos Aires Siglo XXI.

Buxton, R. (2000) El imaginario griego: los contextos de la mitología, Madrid, Akal, 2000

Cabrera, D. H.

(2004) "La matriz imaginaria de las nuevas tecnologías" en Comunicación y Sociedad 17 (1), pp. 9-45 Disponible en http://www.unav.es/fcom/communication-society/es/articulo.php?art_id=72

(2006a) "Hermética y Hermenéutica. Las nuevas tecnologías como imaginario social" en Legete Estudios de Comunicación y Sociedad N6, Junio 2006. Escuela de Periodismo, Universidad Católica de la Santísima Concepción. Disponible en http://es.scribd.com/doc/56966031/Daniel-H-Cabrera-Hermetica-y-Hermeneutica-Las-nuevas-tecnologias-como-imaginario-social

(2006b) Lo tecnológico y lo imaginario. Las nuevas tecnologías como creencias y esperanzas colectivas, Buenos Aires, Biblos

(2011) Comunicación y cultura como ensoñación social, Madrid, Fragua

Casadesús Bordoy, F. (2010) "El arte de tejer como paradigma del buen político en Platón" en Daimon. Revista Internacional de Filosofía, Suplemento 3, 2010, pp. 9-18

Castells, Manuel

(1996) La era de la información, Madrid, Paidos

(2001) La Galaxia Internet. Reflexiones sobre internet, empresa y sociedad, Madrid, Arete

Castoriadis, C.

(1993) La institución imaginaria de la sociedad, Buenos Aires, Tusquets

(2003) Sobre El Político de Platón, Buenos Aires, FCE

Corcuera, R. (2010) Herencia textil andina, Buenos Aires, CEPPA

Couloubaritsis, Lambros "Le paradigme platonicien du tissage comme modèle politique d'une société complexe", Revue de philosophieancienne 13/2, 1995, pp. 107-162.

Derrida, J. (1998) De la Gramatología, México, Siglo XXI

Detienne, M.; Vernant, J.-P. (1988) Las artimañas de la inteligencia. La mētis en la Grecia antigua, Madrid, Taurus

Durand, G. (2004) Las estructuras antropológicas de lo imaginario, México, FCE

Eiroa, J. J. (1994) Historia de la Ciencia y de la Técnica, Tomo 1: La prehistoria, Madrid, Akal

Frontisi-Ducroux, F. (2006) El hombre-ciervo y la mujer-araña. Figuras griegas de la metamorfosis, Madrid, Abada

González Escudero, Santiago "El paradigma de El Político en Platón”, Eikasia. Revista de Filosofía, Extraordinario I, 2007, pp. 69-86.

González Gonzáles, M. (2008)“La mētis de procne. Acerca de Esquilo, Suplicantes 57-61”, Revista Minerva 21. 2008, Universidad de Valladolid, pp. 15-31

Gleick, James (2013) La Información: historia y realidad, Madrid, Crítica

Innis, H. A.

(2007) Empire and communications, Plymouth, Rowman \& Littlefield Publishers

(2012) The Bias of Communication, Toronto, University of Toronto Press

Iriarte, A. (1990) Las redes del enigma. Voces femeninas en el pensamiento griego, Madrid, Taurus.

Mattelart, $A$

(1995) La invención de la comunicación, Barcelona, Bosch

(2000) Historia de la utopía planetaria. De la ciudad profética a la sociedad global. Barcelona, Paidos

McLuhan, M. (1996) Comprender los medios de comunicación, Madrid, Paidos

Melic, A. (2002) "De Madre Araña a demonio Escorpión: Los arácnidos en la Mitología" en ARACNET 10 - Revista Ibérica de Aracnología (Boletín), 5(2002) pp. 112-124.

Ong, W. (2006) Oralidad y escritura. Tecnologías de la palabra, Buenos Aires, FCE 
Papadopoulou-Belmehdi, I. (1996) "Tejidos griegos o lo femenino en antítesis" en Enrahonar, Quaderns de Filosofía, № 26, Barcelona, 1996 pp.25-39.

Ramiro Beltrán, L.; Karina Herrera M.; Esperanza Pinto S.; Torrico V. E. (2008) La comunicación antes de Colón. Tipos y formas en Mesoamérica y los Andes, La Paz, CIBEC

Thompson, J. (1998) Los media y la modernidad: una teoría de los medios de comunicación. Barcelona, Paidós.

Zielinski, Th. (1987) Historia de la civilización antigua, Madrid, Aguilar 